Review

\title{
An Overview on Graphene-Metal Oxide Semiconductor Nanocomposite: A Promising Platform for Visible Light Photocatalytic Activity for the Treatment of Various Pollutants in Aqueous Medium
}

\author{
Soumen Mandal $1,+\left(\mathbb{D}\right.$, Srinivas Mallapur $\left.{ }^{2,+}{ }^{(}\right)$, Madhusudana Reddy ${ }^{2}$, Jitendra Kumar Singh ${ }^{3}(\mathbb{D}$, \\ Dong-Eun Lee ${ }^{4, *(D)}$ and Taejoon Park ${ }^{5, *(D)}$ \\ 1 Intelligent Construction Automation Center, Kyungpook National University, 80 Daehak-ro, Buk-gu, \\ Daegu 41566, Korea; sou.chm@gmail.com \\ 2 Department of Chemistry, REVA University, Kattigenahalli, Yelahanka, Bangalore 560024, Karnataka, India; \\ seenuseenum@gmail.com (S.M.); madhusudana.mb@reva.edu.in (M.R.) \\ 3 Innovative Durable Building and Infrastructure Research Center, Department of Architectural Engineering, \\ Hanyang University, 1271 Sa3-dong, Sangnok-gu, Ansan 15588, Korea; jk200386@hanyang.ac.kr \\ 4 School of Architecture, Civil, Environment, and Energy, Kyungpook National University, 1370, \\ Sangyegk-Dong, Buk-Gu, Daegu 702701, Korea \\ 5 Department of Robotics Engineering, Hanyang University, 55 Hanyangdaehak-ro, Ansan, \\ Gyeonggi-do 15588, Korea \\ * $\quad$ Correspondence: dolee@knu.ac.kr (D.-E.L.); taejoon@hanyang.ac.kr (T.P.); Tel.: +82-3140-05291 (T.P.) \\ + Equal contribution.
}

Received: 9 October 2020; Accepted: 12 November 2020; Published: 17 November 2020

check for updates

\begin{abstract}
Graphene is one of the most favorite materials for materials science research owing to its distinctive chemical and physical properties, such as superior conductivity, extremely larger specific surface area, and good mechanical/chemical stability with the flexible monolayer structure. Graphene is considered as a supreme matrix and electron arbitrator of semiconductor nanoparticles for environmental pollution remediation. The present review looks at the recent progress on the graphene-based metal oxide and ternary composites for photocatalysis application, especially for the application of the environmental remediation. The challenges and perspectives of emerging graphene-based metal oxide nanocomposites for photocatalysis are also discussed.
\end{abstract}

Keywords: graphene oxide; metal oxides; semiconductor; photocatalysis; dyes

\section{Introduction}

Graphene is a 2-D material composed of layers of carbon atoms crammed into a honeycomb network and has become an escalating star on the prospect of materials science in the past many years [1-3]. Graphene can be used to produce 0-D fullerene, 1-D and 3-D graphitic carbon nanotubes that had been intensively studied for the last ten years [4,5]. Graphene exhibits enthralling assets such as extraordinary conductivity, maximum surface-area-to-volume ratio, a fluorescence-quenching competence by electron or energy-allocation, a quantum Hall effect at room temperature, a bipolar electric field effect laterally with the surface conduction of charge carriers and a tunable band gap [6,7]. Narrow band gap metal oxides are of great interest, due to their efficient utilization of solar energy which signifies an auspicious technology to resolve the global energy and eco-friendly challenges [5,8-10]. 
Furthermore, graphene sheets decorated with metal oxide nanoparticles exhibit the outstanding properties because of the synergetic effect between them [11].

The growth of graphene-based composites provides a significant milestone to multiply the application enactment of metal oxide nanomaterials in photocatalysis, as the hybrids have adaptable and suitable properties with superior performances over the individual oxide nanomaterials. With keeping this in mind, considerable efforts have been made on decorating graphene with metal oxides [12]. Graphene-based materials have also been used as the catalyst in the reactions pertaining to environmental remediation [13]. Graphene oxide-based (GO-based)/reduced graphene oxide-based (rGO-based) materials are used as photocatalysts for pollutant abatement [14-17].

In this context, focusing on the recent developments, an attempt is made in the present review to discuss the advantages and disadvantages of the composite in comparison with pristine graphene.

\section{Photocatalysis}

Different metal oxides-GO/rGO composites, their photocatalytic activities and synthesis process are discussed in the following sections as well as in Table 1. However, the photocatalytic performances of metal oxide-GO/rGO composite photocatalysts for the degradation of different pollutants are tabulated in Table 2 .

\subsection{Earth-Abundant Metal Oxide-GO/rGO Composites}

\subsection{1. rGO- $\mathrm{WO}_{3}$ Composites}

rGO- $\mathrm{WO}_{3}$ catalyst dosage has a substantial impression on the photocatalytic activity. The finest Sulfamethoxazole (SMX) removal efficacy was achieved when $\mathrm{rGO}-\mathrm{WO}_{3}-200$ loading was $1.0 \mathrm{~g} \mathrm{~L}^{-1}$, and this study demonstrated that the dosage of the catalyst is crucial for the photocatalytic activity. SMX degradation over $\mathrm{rGO}-\mathrm{WO}_{3}-200$ was significantly influenced by neutral $\mathrm{pH}$ and displayed the pre-eminent process [18]. Photodegradation of naphthol-1 by rGO- $\mathrm{WO}_{3}$-nanocomposite and $\mathrm{WO}_{3}$ was achieved by $84 \%$ and $40 \%$ respectively, attributed to the larger specific surface area and lower band gap energy [19]. Outcomes suggested that the presence of rGO in the nanocomposite enabled the electron transfer [19]. The enhanced photocatalytic activity was due to the synergistic effect between $\mathrm{WO}_{3}$ and $\mathrm{rGO}$ sheets and suppressing the electron-hole pair recombination in the $\mathrm{WO}_{3}-\mathrm{rGO}$ nanocomposite [6]. $\mathrm{WO}_{3} / \mathrm{GO}$ composites revealed an enhanced photocatalysis under the visible light, which was two-folds of pure $\mathrm{WO}_{3}$ that reduced the recombination of the photogenerated electron-hole pairs and increased the visible light absorption efficiency [20].

\subsection{2. $\mathrm{rGO}-\mathrm{Co}_{3} \mathrm{O}_{4}$ Composites}

$\mathrm{Co}_{3} \mathrm{O}_{4} / \mathrm{rGO}$ composite exhibits better photocatalytic activity in a low concentration of Methyl Orange (MO). The higher stocking dose of $\mathrm{Co}_{3} \mathrm{O}_{4}$ on $\mathrm{Co}_{3} \mathrm{O}_{4} / \mathrm{rGO}$ contributes more on the activity [21]. Degradation of organic dyes depicted by photocatalytic experiments where $\mathrm{GO}$ acts as a supporting material and active co-catalyst, which decreases the band gap of $\alpha-\mathrm{MoO}_{3}$ from 2.82 to $2.51 \mathrm{eV}$ [22]. This synthesized hybrid can be used for visible-light-induced photocatalysis. $\mathrm{Co}_{3} \mathrm{O}_{4}$-rGO hybrids were reported to completely oxidize $20 \mathrm{mg} / \mathrm{L}$ phenol in $20 \mathrm{~min}$ at $25^{\circ} \mathrm{C}$. Origination of sulfate radicals via $\mathrm{Co}_{3} \mathrm{O}_{4}$-mediated activation of peroxymonosulfate (PMS) is responsible for this catalytic effect [23]. The $\mathrm{Co}_{3} \mathrm{O}_{4} / \mathrm{N}$-doped graphene hybrid exhibits similar catalytic activity but superior stability to $\mathrm{Pt}$, in alkaline solutions. This unusual catalytic activity arises from synergetic chemical coupling effects between $\mathrm{Co}_{3} \mathrm{O}_{4}$ and graphene [23].

\subsubsection{GO/rGO-TiO 2 Composites}

A systematic investigation on the photocatalytic properties of $\mathrm{TiO}_{2}-\mathrm{GO}$ nanocomposites was examined with different ratios of graphene additions and it was found that higher amount of graphene addition decreased the photocatalytic activity [24]. Liquid-phase degradation of dyes over the $\mathrm{TiO}_{2}-\mathrm{GO}$ 
photocatalyst showed the similar occurrence. This study demonstrated that $\mathrm{TiO}_{2}-\mathrm{GO}$ cannot offer truly new visions into the assembly of $\mathrm{TiO}_{2}$ carbon composite as high-performance photocatalysts. $\mathrm{The}^{\mathrm{TiO}} \mathrm{O}_{2}$ particles were found to be in anatase phase and a narrow size distribution was dispersed on the surface of graphene sheets uniformly [25]. A comparison of photoluminescence spectra between $\mathrm{TiO}_{2}$ and $\mathrm{G}-\mathrm{TiO}_{2}$ was reported with different reaction times, as shown in Figure 1. In this figure, the inset is the amplificatory image of the area in the range of 300 to $500 \mathrm{~nm}$ which demonstrates the quenching extent in relation with the reaction time in the Graphene- $\mathrm{TiO}_{2}$ [26]. $\mathrm{TiO}_{2}$ (P25)- $\mathrm{rGO}$ composite was found to be the most proficient photocatalyst for the degradation of Methylene Blue (MB) and the optimum mass ratio was found to be 1/0.2 [14]. Comparison has revealed that the P25-rGO composite has additional effectiveness compared to the P25-CNT (carbon nanotubes) composite (Figure 2).

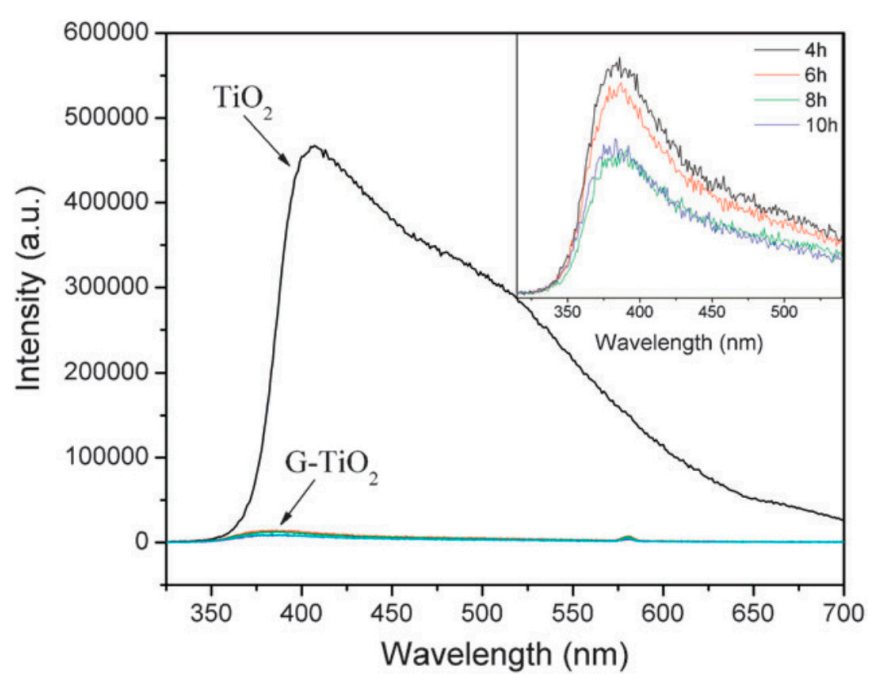

Figure 1. Photoluminescence spectra of $\mathrm{TiO}_{2}$ and $\mathrm{G}-\mathrm{TiO}_{2}$ composite with various reaction times. The inset shows amplificatory image (300 to $550 \mathrm{~nm})$ [26].
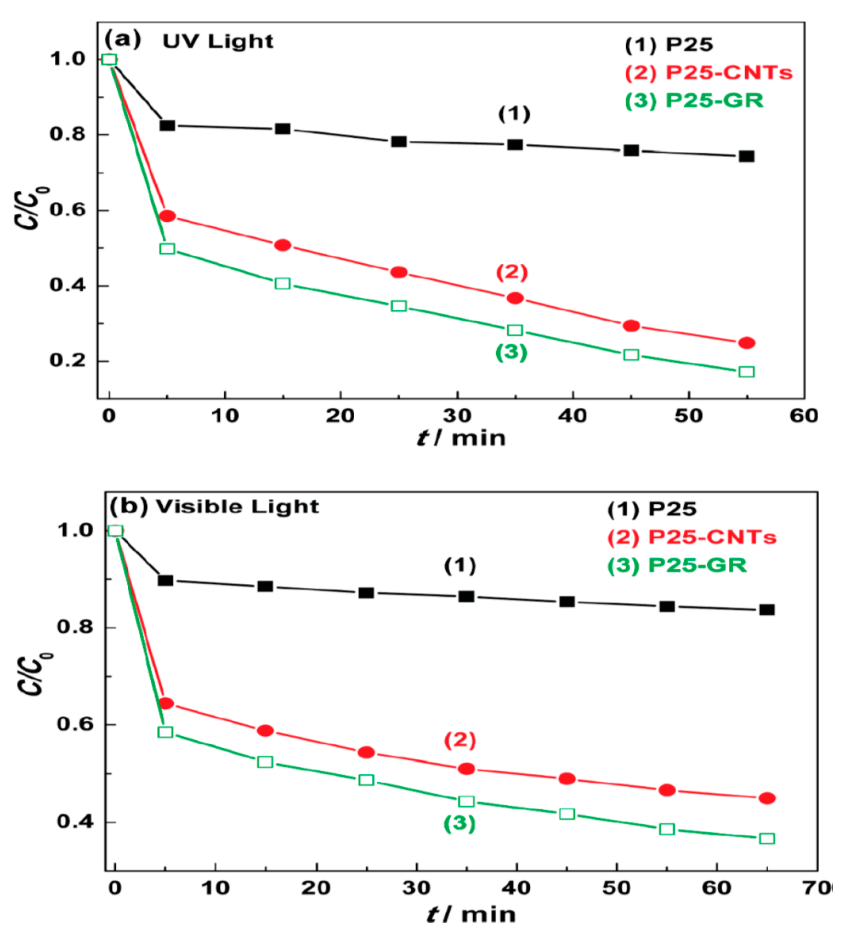

Figure 2. Degradation of Methylene Blue under (a) UV and (b) visible light ( $\lambda>400 \mathrm{~nm}$ ) over (1) P25, (2) P25-carbon nanotubes (CNTs), and (3) P25-GR photocatalysts, respectively [14]. 
Graphene-loaded $\mathrm{TiO}_{2}$ films were reported to be highly conductive and transparent; remarkably, graphene/ $\mathrm{TiO}_{2}$ films exhibited super hydrophilicity in a short time even under a white fluorescent light bulb. Higher photocatalytic activity owed to its efficient charge separation and electrons injection from the conduction band of $\mathrm{TiO}_{2}$ to graphene [27].

The higher photocatalytic performance was observed in $\mathrm{TiO}_{2}$-graphene oxide composite due to the formation of both $\pi-\pi$ conjugations between dye molecules and aromatic rings. The photocatalytic property was reported to be higher with the higher content of the graphene oxide. Furthermore, ionic interactions between $\mathrm{MB}$ and functional groups of GO on the surfaces of carbon-based nanosheets was also the reason considered for the superior property [28]. Improving graphene oxide (IGO) in strong acidic condition was reported to enhance the chemical interaction between $\mathrm{TiO}_{2}$ and graphene sheets [29]. This study showed that $\mathrm{IGO}$ can react with $\mathrm{Ti}(\mathrm{OH})_{\mathrm{x}}$ to form graphene/ $\mathrm{TiO}_{2}$ composite in situ, with complete and near coverage of Ti-C and Ti-O-C carbonaceous bonds at the graphene/TiO 2 interface. Higher photocatalytic activity shown by graphene/ $\mathrm{TiO}_{2}$ due to effective charge transfer imparts under visible light and GO forms chemical bonds at the interface [29].

Photocatalytic experiments using sacrificial hole and radical scavenging agents demonstrated that the photogenerated holes are the main reason for the degradation of diphenhydramine (DP), both under UV and visible light. In this report, photoluminescence studies revealed discrete appeasing of the GO photoluminiscence under visible light and near infrared laser excitation. Hence, it was conferred that GO acts as either an electron acceptor or donor of $\mathrm{TiO}_{2}$ under UV/visible light [30].

Nitrogen-doped $\mathrm{P90} \mathrm{TiO}_{2}$ (N-P90), nitrogen-doped reduced graphene oxide (N-rGO), as well as their composites were studied for the photocatalytic activity. N-P90/N-rGO showed enhanced photocatalytic activity, and in the presence of this composite, around $80 \% \mathrm{MB}$ was degraded by visible light irradiation in $160 \mathrm{~min}$. Enhanced photocatalytic performance is observed in N-P90/N-rGO composites for degradation of $\mathrm{MB}$ due to photo-induced and electronic interaction between $\mathrm{TiO}_{2}$ and graphene. Comparison of degradation efficiency of $\mathrm{MB}$ under visible light irradiation by $\mathrm{P} 90$ $\mathrm{TiO}_{2}, \mathrm{~N}-\mathrm{P90}$, and N-P90/rGO is presented in Figure 3 [31]. It is reported that the rGO or N-rGO in the composite enables the separation of electrons and holes by performing as electron trapping/de-trapping under visible light [31]. Ultrafine $\mathrm{TiO}_{2}$ nanofibers ( $10 \mathrm{~nm}$ diameters) were synthesized from electrospun rice-shaped $\mathrm{TiO}_{2}$ and potassium titanate was achieved from rice-shaped $\mathrm{TiO}_{2}$. The surface area was increased by 2.5 times after the nanofiber formation of $\mathrm{TiO}_{2}$. The results showed that the photodegradation of $\mathrm{MO}$ was found to be higher than bare $\mathrm{TiO}_{2}(\mathrm{P}-25)$ nanoparticles [32]. $\mathrm{GO} / \mathrm{TiO}_{2}$ of different composition ratios were tested and the formulation of catalyst with 1.2 times higher photocatalytic activity than commercial photocatalyst was reported. This catalyst was able to degrade $3 \mathrm{mg} / \mathrm{L} \mathrm{MB}$ over 10 consecutive cycles with nominal loss in photocatalytic efficacy. Graphene plays a generous part in obstructing the accretion of $\mathrm{TiO}_{2}$ grains upon calcination at high temperature [33] A set of reduced graphene oxide- $\mathrm{TiO}_{2}\left(\mathrm{rGO}-\mathrm{TiO}_{2}\right)$ nanocomposites was synthesized and examined for the photocatalytic activity by decolorization of Rhodamine B dye (RhB) under UV light. In this study, various parameters, such as dye concentration, rGO content, catalytic dose, and pH, were optimized for the decolorization. The catalysts were found to be more active at natural $\mathrm{pH}$ of the dye under the UV-illumination for the degradation of RhB dye. The presence of $\mathrm{H}_{2} \mathrm{O}_{2}$ and $\mathrm{K}_{2} \mathrm{~S}_{2} \mathrm{O}_{8}$ increased the decolorization. Further, addition of $\mathrm{CO}_{3}{ }^{2-}$ and $\mathrm{Cl}^{-}$ions decreased the dye degradation rate [34].

$\mathrm{TiO}_{2}$ nanoparticle-attached graphene/carbon composite nanofibers $\left(\mathrm{TiO}_{2}-\mathrm{CCNFs}\right)$ were synthesized and reported as highly active photocatalysts for photocatalytic degradation of $\mathrm{MB}$ under the irradiation of visible light. Graphene was suggested to play the role of an electron acceptor and a photosensitizer, resulting in a higher photodegradation rate and reduced electron-hole pair recombination. CNFs having high surface also improved the photocatalytic activity of $\mathrm{TiO}_{2}$ [35]. 

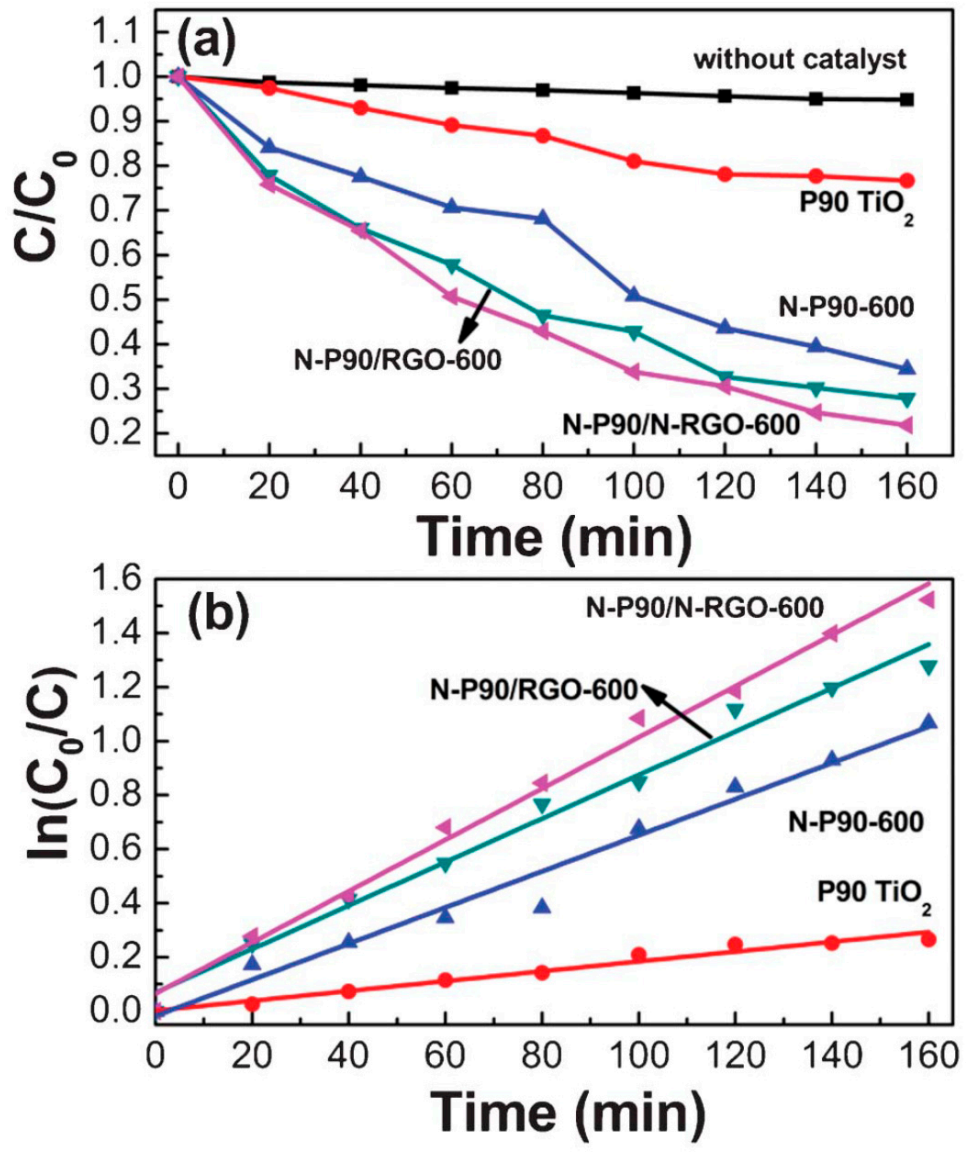

Figure 3. (a,b) Degradation of $\mathrm{MB}$ under visible light irradiation by $\mathrm{P} 90 \mathrm{TiO}_{2}, \mathrm{~N}-\mathrm{P} 90-600, \mathrm{~N}-\mathrm{P} 90 /$ reduced graphene oxide (rGO)-600, N-P90/N-rGO-600, and without catalyst [31].

\subsubsection{GO/rGO-ZnO Composite}

An effective scalable method was developed to make nanocomposites of functional graphene sheets (FGS)/ZnO. In this study, poly (vinyl pyrrolidone) (PVP) component was reported to play a crucial role for loading of $\mathrm{ZnO}$ nanoparticles onto FGS by connecting $\mathrm{Zn}$ ions on the carbon materials and promoting $\mathrm{ZnO}$ nucleation and crystal growth in the precursor-prepared route. Further, FGS/ZnO composite was evaluated for photocatalytic activity and was found to be applicable for a number of environmental issues [36]. $\mathrm{ZnO} / \mathrm{rGO}$ nanocomposite was used as a photocatalyst for the removal of MB. Observations showed that the efficiency of the photocatalyst activity of the $\mathrm{ZnO}$ nanoparticles was significantly increased by rGO [37].

The calcination atmosphere was found to affect the photocatalytic activity of the $\mathrm{TiO}_{2} /$ graphene sheet (GS) (5\%) composites for $\mathrm{H}_{2}$ evolution from water splitting. This study demonstrated that beyond the critical content of GS (5\%), photocatalytic activity was decreased by initiating electron-hole recombination centers. Calcination atmosphere was found to be important and better performance was observed for the samples calcined in nitrogen atmosphere [38].

The use of $\mathrm{ZnO}$-graphene composites (Z-GC) was reported to remove dye from water due to the interaction between the graphene sheets and the $\mathrm{ZnO}$ nanoparticles [39]. rGO- $\mathrm{ZnO}$ (3.56\%) showed higher photocurrent response and degradation of MB under illumination of UV light. Longer electron lifetime and the enhanced light absorption were verified by analytical and electrochemical technique (Figure 4) [40]. 


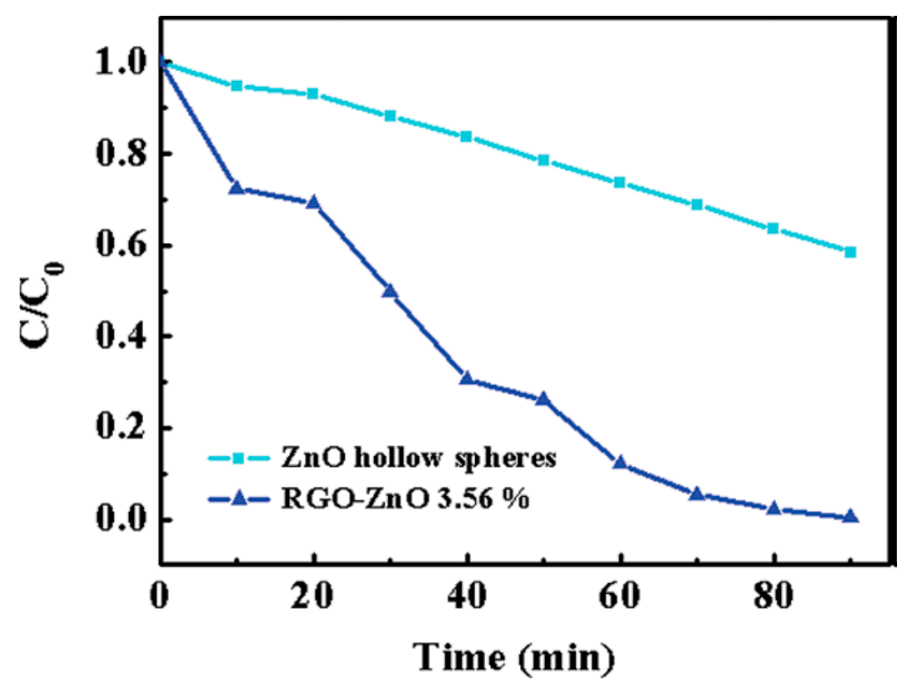

Figure 4. Photocatalytic activity of $\mathrm{ZnO}$ hollow spheres and $\mathrm{rGO}-\mathrm{ZnO} 3.56 \%$ for the degradation of MB under UV illumination [40].

The $\mathrm{ZnO} / \mathrm{GO}$ nanocomposite consisting of flower-like $\mathrm{ZnO}$ nanoparticles anchored on graphene-oxide. Further, photocatalytic efficiency of $\mathrm{ZnO} / \mathrm{GO}$ composite progressed by annealing the product in $\mathrm{N}_{2}$ atmosphere. The superior photocatalytic performance was due to the synergistic effect of the proficient electron inoculation and low charge carriers in the composite, where GO acted as an electron collector and transporter, leading to unceasing generation of reactive oxygen species for the

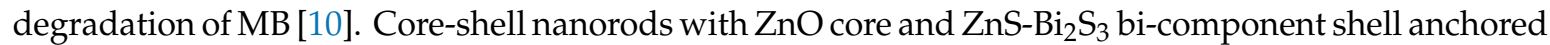
on the rGO sheets were synthesized and reported to show a broad and strong photo-absorption in the visible region. These nanorods also manifested better photocatalytic activity for $\mathrm{H}_{2}$ evolution from the glycerol-water mixtures. The superiority in performance is owing to the elevated light absorption and effective charge separation [41].

\subsection{Bimetal Oxide-GO/rGO Composites}

\subsection{1. $\mathrm{GO} / \mathrm{rGO}-\mathrm{CoFe}_{2} \mathrm{O}_{4}$ Composite}

Connexion of the graphene suggestively progressed the photocatalytic performance of the $\mathrm{CoFe}_{2} \mathrm{O}_{4}$ in which the graphene acts as a charge carrier to detain the delocalized electrons. Photocatalytic activity was explored with the variation of the dosage and dye concentration [42]. $\mathrm{CoFe}_{2} \mathrm{O}_{4}$-graphene hybrid materials (CFGHs) showed ferromagnetic behavior and enhanced photodegradation rate and amended adsorbing capacity due to the assimilation of graphene [43]. The photodegradation fallouts directed the visible light fascinating performance of the ternary photocatalysts and formation of the $\mathrm{p}-\mathrm{n}$ junction between $\mathrm{CoFe}_{2} \mathrm{O}_{4}$ and $\mathrm{CdS}$. Escalation in the concentration of $\mathrm{MB}$ was observed as the irradiation time increased for $\mathrm{CoFe}_{2} \mathrm{O}_{4}$ due to the desorption of $\mathrm{MB}$ during irradiation. $\mathrm{G}-\mathrm{CoFe}_{2} \mathrm{O}_{4} / \mathrm{CdS}$ easily separated from aqueous solution in an external magnetic field, as seen from the digital photos of $\mathrm{Gr}-\mathrm{CoFe}_{2} \mathrm{O}_{4} / \mathrm{CdS}$ after irradiation [44]. The $\mathrm{CoFe}_{2} \mathrm{O}_{4}-\mathrm{rGO}$ composite unveiled required photocatalytic performance with excellent recycling stability for the degradation of $\mathrm{MB}, \mathrm{RhB}$, and $\mathrm{MO}$ under visible-light irradiation [45].

$\mathrm{CoFe}_{2} \mathrm{O}_{4}-\mathrm{rGO}(\mathrm{CF}-\mathrm{rGO})$ nanocomposites hold exceptional microwave absorbing properties and high photocatalytic activity for the degradation of various dyes under visible light irradiation [46]. 85 CF-15 rGO exposed admirable microwave absorption possessions with a Reflection Loss (RL) of $31.31 \mathrm{~dB}$ (99.94\% absorption) at $9.05 \mathrm{GHz}$, with an 8.2-10.92 GHz effective bandwidth range. 75CF-25 rGO was found to be a good magnetically separable photocatalyst for the degradation of dyes, MO, MB, and $\mathrm{RhB}$, under visible light irradiation emitted from a $100 \mathrm{~W}$ reading lamp [46]. The photocatalytic activity was found to be affected by the structural and optical properties and surface area of the samples [47]. 
$\mathrm{CoFe}_{2} \mathrm{O}_{4}-3 \mathrm{D} \mathrm{TiO}_{2}$ nanocomposite showed an enhancement in the photodegradation of $\mathrm{MB}$ as compared to the commercial rutile-phase $\mathrm{TiO}_{2}$ and the pure urchin-like $\mathrm{TiO}_{2}\left(3 \mathrm{D} \mathrm{TiO}_{2}\right)$ microparticles. Results specified that the composite showed relatively consistent photocatalytic activity with slight degradation [48]. The photocatalytic activity of 75CF-25 rGO was found to be analogous and in some cases, superior, compared to the several reported $\mathrm{rGO}-\mathrm{CoFe}_{2} \mathrm{O}_{4}$ composites [46]. The photocatalytic activity of CF-RGO was increased with increasing rGO content in composites until $25 \mathrm{wt} \%$ of $\mathrm{rGO}$, and degradation takes place around $60 \mathrm{~min}$.

The photocatalytic degradation of short-chain chlorinated paraffin's over $\mathrm{rGO} / \mathrm{CoFe}_{2} \mathrm{O}_{4} / \mathrm{Ag}$ under visible light $(\lambda>400 \mathrm{~nm})$ was investigated by in-situ Fourier transform infrared spectroscopy and the correlated mechanisms were suggested. Superficial degradation ratio of $91.9 \%$ over rGO/CoFe $\mathrm{O}_{4} / \mathrm{Ag}$ was obtained under visible light illumination of $12 \mathrm{~h}$, while only about $21.7 \%$ was obtained with commercial P-25 $\mathrm{TiO}_{2}$ [49]. Increase of $\mathrm{rGO}$ caused an increase in the completion time of the photocatalysis. Degradation of $\mathrm{MO}$ diminished with increasing catalyst dose up to $500 \mathrm{mgL}^{-1}$, and then, no noteworthy decrease of time was observed when more catalyst was added. Likewise, use of $2 \mathrm{~mL}$ of $\mathrm{H}_{2} \mathrm{O}_{2}$ was found to be an optimum amount for the photocatalysis reaction (Figure 5) [46]. Photocatalytic activity of the $\mathrm{rGO}-\mathrm{CoFe}_{2} \mathrm{O}_{4}$ nanocomposites was queried for the degradation of 4-Chlorophenol (4-CP) under visible light illumination. Activity of rGO-CoFe $\mathrm{O}_{4}$ composite was seen in the occurrence of PMS (Figure 6) [50].
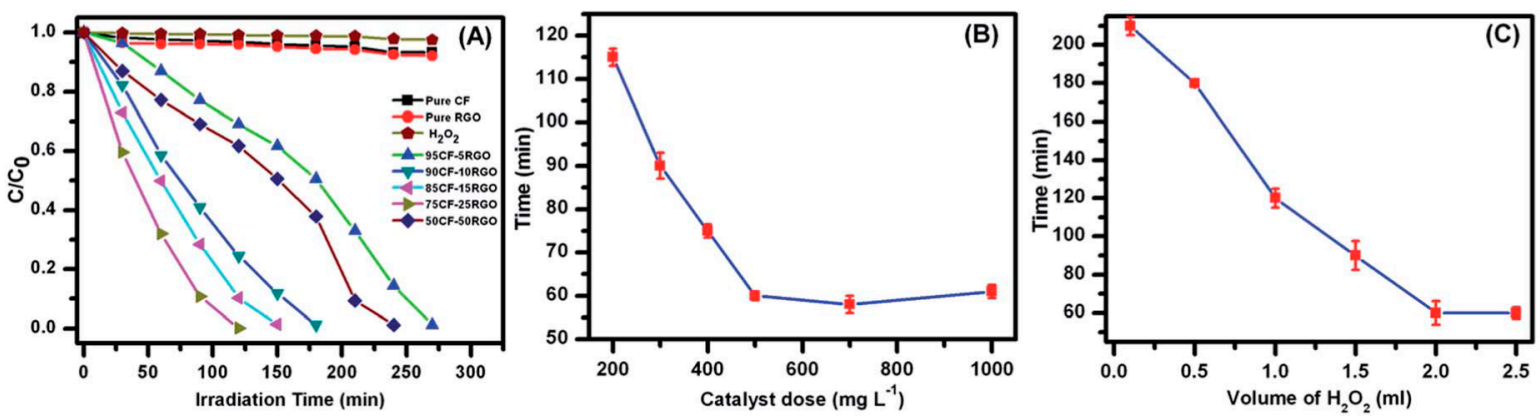

Figure 5. (A) Different catalysts for the degradation of Methyl Orange (MO) under visible light. (B) Catalyst dosage and (C) $\mathrm{H}_{2} \mathrm{O}_{2}$ on the accomplishment time of photocatalysis reaction of $\mathrm{MO}$ catalyzed by 75CF-25RGO [46].

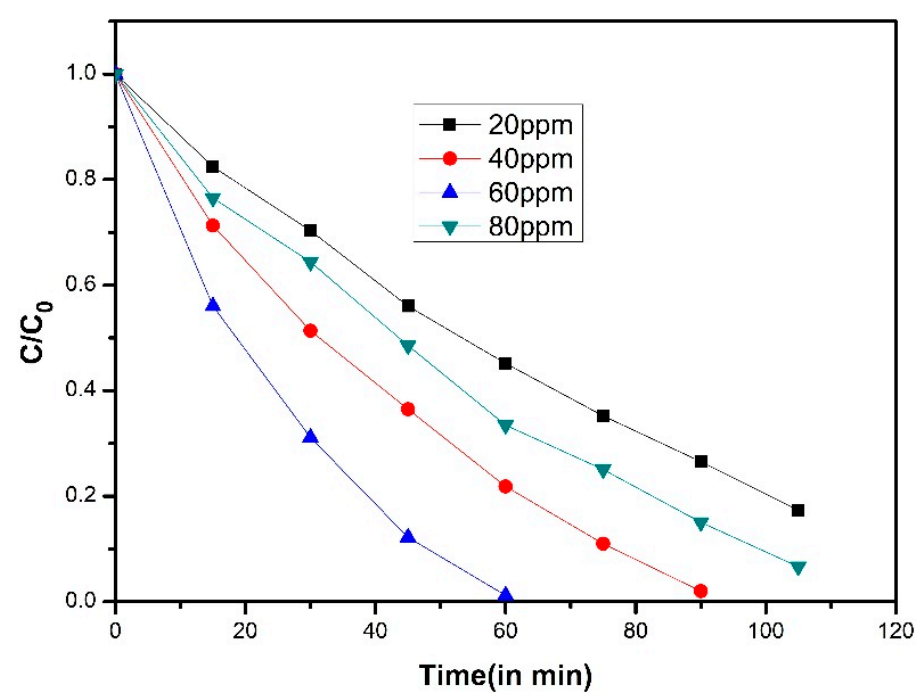

Figure 6. Plot of $C / C_{o}$ vs. time in min for the degradation of $4-C P(10 \mathrm{ppm})$ with $100 \mathrm{mg}$ of catalyst at various peroxymonosulfate (PMS) concentrations [50]. 


\subsubsection{GO-rGO- $\mathrm{ZnFe}_{2} \mathrm{O}_{4}$ Composite}

Photocatalytic activity of $\mathrm{ZnFe}_{2} \mathrm{O}_{4}$-graphene catalyst demonstrated an important two-fold function as the photoelectrochemical degradation of $\mathrm{MB}$ and generation of hydroxyl radical for the decomposition of $\mathrm{H}_{2} \mathrm{O}_{2}$ under visible light irradiation [51]. Graphene- $\mathrm{ZnFe}_{2} \mathrm{O}_{4}$ photocatalyst facilitated the transport channels for photon-excited electrons from the surface of the catalyst. As a result, about $20 \mathrm{~nm} \mathrm{ZnFe}_{2} \mathrm{O}_{4}$ catalyst with a highly crystallized (311) plane confined in the graphene network exhibited an excellent visible-light-driven photocatalytic activity with an ultrafast degradation rate of $1.924 \times 10^{-7} \mathrm{~mol} \mathrm{~g}^{-1} \mathrm{~s}^{-1}$ for MB [52].

The boosted photocatalytic activity of $\mathrm{ZnFe}_{2} \mathrm{O}_{4}-\mathrm{rGO}$ nanocomposite was shown due to the active restraint of the recombination of the photo-excited electron-hole pairs by $\mathrm{rGO}$ sheets and the generation of $\cdot \mathrm{OH}$-free radical [11]. The photocatalytic activity of the nanocomposite examined under visible light, for the degradation of $17 \alpha$-ethinylestradiol $\left(\mathrm{EE}_{2}\right)$ [50]. The pseudo rate constant of $\mathrm{ZnFe}_{2} \mathrm{O}_{4}-\mathrm{Ag} / \mathrm{rGO}$ nanocomposite was higher by the factor of 14.6 and 5.6 times over its counterparts. Photosensitization effect was prevailed by good interaction ensuing in only $80 \%$ removal of $\mathrm{EE}_{2}$ though humic acid [53]. $\mathrm{rGO} / \mathrm{ZnFe}_{2} \mathrm{O}_{4}$ composite exhibited the remarkable catalytic activity toward $\mathrm{MB}$ degradation; in the presence of $\mathrm{H}_{2} \mathrm{O}_{2}$, the activity enhanced, and the reaction followed a pseudo-first-order kinetics. The complete $\mathrm{MB}$ degradation observed at $\mathrm{rGO} / \mathrm{ZnFe}_{2} \mathrm{O}_{4}$ composites was attributed to the $\pi-\pi$ interaction, hydrogen bonding, and electrostatic interaction exerted between the $\mathrm{rGO}$ and $\mathrm{ZnFe}_{2} \mathrm{O}_{4}[54]$.

\subsection{3. $\mathrm{GO} / \mathrm{rGO}-\mathrm{NiFe}_{2} \mathrm{O}_{4}$ and $\mathrm{MnFe}_{2} \mathrm{O}_{4}$ Composites}

$\mathrm{NiFe}_{2} \mathrm{O}_{4}$-GO (0.25) hetero-architecture demonstrated a considerable lesser emission intensity. Due to their competent electron-transport property, graphene sheets can deliberately reduce the fluorescence of $\mathrm{NiFe}_{2} \mathrm{O}_{4}$ fixed on them. Kinetic results indicated that the rate-determining step is the adsorption course of $\mathrm{MB}$ [55]. In this study, $\mathrm{NiFe}_{2} \mathrm{O}_{4}-\mathrm{GO}(0.25)$ shows the best activity compared to other $\mathrm{NiFe}_{2} \mathrm{O}_{4}-\mathrm{G}$ composites (Figure 7). $\mathrm{GO}-\mathrm{NiFe}_{2} \mathrm{O}_{4}$ showed photo-Fenton reactions for organic contaminants in the presence of both $\mathrm{H}_{2} \mathrm{C}_{2} \mathrm{O}_{4}$ and $\mathrm{H}_{2} \mathrm{O}_{2}$ under visible light irradiation. The photochemical reduction of $\mathrm{Fe}^{3+}$ ions by GO was a key step in inducing the Fenton process [56]. The superior photocatalytic is due to (I) high visible absorbance for charge carrier production, (II) the electrons captured by Au nanoparticles results in the fast separation, and (III) the strong surface plasmon resonance (SPR) of Au nanoparticles permit the generation of high concentration of charge carriers [57]. $\mathrm{MnFe}_{2} \mathrm{O}_{4}$ catalyst is photocatalytically inactive. The noteworthy higher photocatalytic activity is due to the $\mathrm{rGO}$, as the excellent conductivity in the $\mathrm{MnFe}_{2} \mathrm{O}_{4}$ and graphene composite [58].
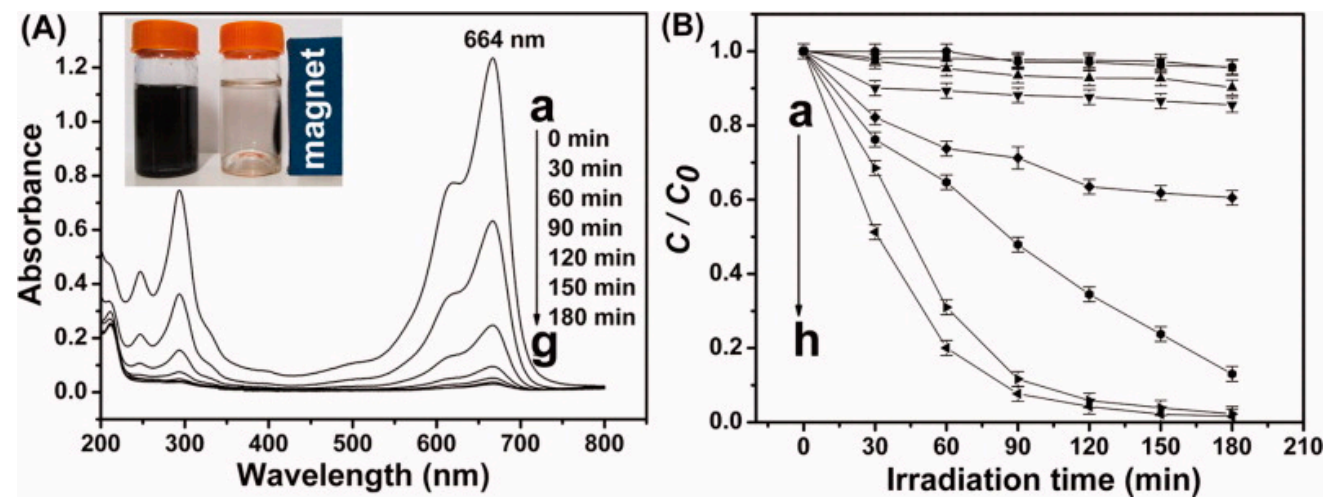

Figure 7. Absorption spectra of $\mathrm{MB}$ taken at various photocatalytic degradation times consuming $\mathrm{NiFe}_{2} \mathrm{O}_{4}$-GO (0.25) [55]. (A) The magnetic separation property of $\mathrm{NiFe}_{2} \mathrm{O}_{4}$-graphene nanocomposite is shown in the inset, (B) different catalysts and their photocatalytic degradation efficiency on MB: (a) pure $\mathrm{NiFe}_{2} \mathrm{O}_{4}$, (b) $\mathrm{NiFe}_{2} \mathrm{O}_{4}-\mathrm{G}(0.05)$, (c) $\mathrm{NiFe}_{2} \mathrm{O}_{4}-\mathrm{G}(0.10)$, (d) $\mathrm{NiFe}_{2} \mathrm{O}_{4}-\mathrm{G}(0.15)$, (e) $\mathrm{NiFe}_{2} \mathrm{O}_{4}-\mathrm{G}(0.20)$, (f) $\mathrm{NiFe}_{2} \mathrm{O}_{4}-\mathrm{G}(0.40),\left(\right.$ g) $\mathrm{NiFe}_{2} \mathrm{O}_{4}-\mathrm{G}(0.30)$, and (h) $\mathrm{NiFe}_{2} \mathrm{O}_{4}-\mathrm{G}(0.25)$. 


\subsubsection{Other Composite Systems}

RGO-Bi ${ }_{2} \mathrm{WO}_{6}$ and 3D CNT-pillared rGO nanocomposites show outstanding photocatalytic performance for the degradation of dyes under visible light [59]. $\mathrm{BiFeO}_{3}$-graphene nanohybrids have a six times higher rate compared to $\mathrm{BiFeO}_{3}$ for the degradation of Congo Red (CR) under visible light due to its combined effects of modulated band gap and covalent bonding between $\mathrm{BiFeO}_{3}$ and graphene [60].

Photoluminescence studies of $\mathrm{Nb}_{3} \mathrm{O}_{7}(\mathrm{OH})$ - $\mathrm{RGO}$ composite supported the suggested mechanism of charge separation and transport mechanism. A higher degradation rate was obtained using the nanocomposite prepared with a graphene loading of $3 \mathrm{mgmL}^{-1}$, and when the rGO loading exceeded $3 \mathrm{mgmL}^{-1}$, degradation efficacy diminished. This arose as extra rGO sheets gathered and stuck the absorption of incident light [61].

\section{Photocatalytic Evaluation}

Pristine $\mathrm{TiO}_{2}$ and $\mathrm{ZnO}$ exhibited good photocatalytic activity in UV light due to their wide band gap. These two metal oxides are stable in aqueous conditions during photocatalysis. Further, coupling of graphene with $\mathrm{TiO}_{2}$ and $\mathrm{ZnO}$ increases the photocatalytic activity due to increases in the photogenerated charge carriers. Metal oxides with magnetic properties of metal ferrites $\left(\mathrm{MFe}_{2} \mathrm{O}_{4}\right)$ offer an added advantage as photocatalysts since they can be recovered by applying an external magnetic field after catalysis. Metal ferrites $\left(\mathrm{MFe}_{2} \mathrm{O}_{4}, \mathrm{M}=\mathrm{Co}, \mathrm{Ni}, \mathrm{Mn}, \mathrm{Zn}\right.$, etc.) materials are proven to be excellent candidates for visible light photocatalytic $\mathrm{H}_{2}$ generation through water splitting. Recycling ability for metal ferrites are far better compared to nano semiconductors like $\mathrm{TiO}_{2}$ and $\mathrm{ZnO} . \mathrm{MFe}_{2} \mathrm{O}_{4}$ is a class of semiconductor with narrow band gap, which exhibits characteristic visible light response, possess good photochemical stability, and exhibits excellent optical properties.

$\mathrm{MFe}_{2} \mathrm{O}_{4}$ absorbs $42-45 \%$ of sunlight, whereas $\mathrm{TiO}_{2}$ and $\mathrm{ZnO}$ absorbs $4 \%$ of sunlight. $\mathrm{MFe}_{2} \mathrm{O}_{4}$ are efficient for the degradation of dye degradation and organic pollutant degradation compared to the other metal oxides $\left(\mathrm{SnO}_{2}, \mathrm{CeO}_{2}, \mathrm{BaTiO}_{3}\right.$, and $\left.\mathrm{SrTiO}_{3}\right)$, with respect to the catalyst and the light source. In $\mathrm{MFe}_{2} \mathrm{O}_{4}$ context, recombination of photogenerated charge carriers is the major limitation in semiconductor photocatalysis as it reduces the overall quantum efficiency. In order to enhance the photocatalytic activity, graphene material is coupled with $\mathrm{MFe}_{2} \mathrm{O}_{4}$, where the graphene channels the electrons. Comparison of degradation rate for various photocatalytic reaction systems is incongruous since the nature of catalyst and substrate pollutant molecules are different in each reaction. Ferrite nanoparticles have a strong magnetic property, which can be easily used for magnetic separation after photo-mineralization.

The photocatalytic efficiency depends on the ratio of the photogenerated charge-carrier transfer rate to the rate of electron-hole recombination. For composite structure, $\mathrm{M}^{2+}$ ion easily bonds with oxygen by giving an electron and super oxide radical. This super oxide radical can oxidize the organic substrate molecule. The $\mathrm{Fe}^{3+}$ ion and $\mathrm{Fe}^{2+}$ ions can show photo-Fenton reactions in presence of in-situ-generated $\mathrm{H}_{2} \mathrm{O}_{2}$. This $\mathrm{H}_{2} \mathrm{O}_{2}$ generates hydroxyl-free radicals, which are involved in the degradation of pollutants. Predicted mechanism for the $\mathrm{rGO}-\mathrm{CoFe}_{2} \mathrm{O}_{4}$ composite is shown in Equations (1)-(4).

$$
\begin{gathered}
\mathrm{rGO}\left(\mathrm{e}^{-}\right)-\mathrm{CoFe}_{2} \mathrm{O}_{4}\left(\mathrm{~h}^{+}\right)+\mathrm{O}_{2} \rightarrow \mathrm{rGO}-\mathrm{CoFe}_{2} \mathrm{O}_{4}\left(\mathrm{~h}^{+}\right)+\mathrm{O}_{2}^{\bullet-} \\
\mathrm{rGO}-\mathrm{CoFe}_{2} \mathrm{O}_{4}\left(\mathrm{~h}^{+}\right)+\mathrm{OH}^{-} / \mathrm{H}_{2} \mathrm{O} \rightarrow \mathrm{rGO}-\mathrm{CoFe}_{2} \mathrm{O}_{4}+{ }^{\bullet} \mathrm{OH} \\
\mathrm{rGO}\left(\mathrm{e}^{-}\right)-\mathrm{CoFe}_{2} \mathrm{O}_{4}\left(\mathrm{~h}^{+}\right)+\mathrm{HSO}_{5}^{-} \rightarrow \mathrm{rGO}-\mathrm{CoFe}_{2} \mathrm{O}_{4}+{ }^{\bullet} \mathrm{OH}+\mathrm{SO}_{4}^{\bullet-} \\
\mathrm{SO}_{4}^{\bullet-}+\mathrm{H}_{2} \mathrm{O} \rightarrow \mathrm{HSO}_{4}^{-}+{ }^{\bullet} \mathrm{OH}
\end{gathered}
$$

rGO-BiO 6 composite shows better photocatalyst compared to other catalysts prepared from hydrothermal method (Table 1; Table 2). The enhanced photocatalytic activity could be endorsed to the negative shift in the Fermi level of graphene-Bi2WO6 (G-BWO), decrease the conduction 
band potential, and elevate migration efficiency of photo-induced electrons, which may restrain the charge recombination efficiently. Superior contact between $\mathrm{BiVO}_{4}$ and $\mathrm{rGO}$ scaffold subsidizes to photo-response augmentation compared to other electrochemical methods in the $\mathrm{rGO}-\mathrm{BiO}_{4}$ composite.

Table 1. Photocatalysts and their typical synthetic methods used for the preparation from GO/rGO-supported composites.

\begin{tabular}{|c|c|c|c|}
\hline Order & Photocatalyst & Preparation & References \\
\hline \multicolumn{4}{|c|}{ A. Hydrothermal method for the synthesis of GO/rGO-NCs photocatalyst } \\
\hline 1 & $\mathrm{rGO}-\mathrm{WO}_{3}$ & $\begin{array}{l}\mathrm{Na}_{2} \mathrm{WO}_{4} \cdot 2 \mathrm{H}_{2} \mathrm{O} \text { and } 0.05 \mathrm{~g} \mathrm{NaCl} \text { were dissolved in } \\
\text { the above dispersion and kept stirring for } 1 \mathrm{~h} \text {. } \\
\text { The } \mathrm{pH} \text { was adjusted to } 2 \text { by using } \mathrm{HCl} \text { solution. }\end{array}$ & [6] \\
\hline 2 & $\mathrm{rGO}-\mathrm{WO}_{3}$ & $\begin{array}{c}\text { Preset amounts of } \mathrm{Na}_{2} \mathrm{WO}_{4} \cdot 2 \mathrm{H}_{2} \mathrm{O}(100,200, \\
\text { and } 400 \mathrm{mg} \text {, respectively) were dissolved in } 10 \mathrm{~mL} \\
\text { above GO suspension. } 5 \mathrm{~mL} 35 \% \mathrm{HCl} \text { was added } \\
\text { slowly. Transferred to autoclave heated at } 140^{\circ} \mathrm{C} \\
\text { for } 8 \mathrm{~h} \text {. }\end{array}$ & [18] \\
\hline 3 & $\mathrm{rGO}_{-} \mathrm{Co}_{3} \mathrm{O}_{4}$ & $\begin{array}{l}\text { GO dispersed into } 24 \mathrm{~mL} \text { of alcohol, sonicating for } \\
60 \mathrm{~min} \text { in an ultrasonic cleaner. Then, } 0.2 \mathrm{M} \text { of } \\
\mathrm{Co}(\mathrm{Ac})_{2} \text { was added to the mixture followed by } \\
1.2 \mathrm{~mL} \text { of water, and continued to be stirred for } 10 \mathrm{~h} \\
\text { at a temperature of } 80^{\circ} \mathrm{C} \text {. The resulting solution was } \\
\text { then transferred into a } 40 \mathrm{~mL} \text { autoclave for } \\
\text { hydrothermal reaction at } 150^{\circ} \mathrm{C} \text { for } 3 \mathrm{~h} \text {. }\end{array}$ & [21] \\
\hline 4 & rGO_Co ${ }_{3} \mathrm{O}_{4}$ & $\begin{array}{l}\text { GO dispersed in the } \mathrm{Co}\left(\mathrm{C}_{2} \mathrm{H}_{3} \mathrm{O}_{2}\right)_{2} \cdot 4 \mathrm{H}_{2} \mathrm{O} .10 \mathrm{~mL} \\
\text { with } 28 \% \text { ammonia solution were added to solution, } \\
\text { and transferred into an autoclave for hydrothermal } \\
\text { action at } 180{ }^{\circ} \mathrm{C} \text { for } 12 \mathrm{~h} \text {. }\end{array}$ & [23] \\
\hline 5 & $\mathrm{rGO} / \mathrm{ZnFe}_{2} \mathrm{O}_{4}-\mathrm{Ag}$ & $\begin{array}{l}\text { The composite was synthesized by the } \\
\text { co-precipitation of } \mathrm{Zn}\left(\mathrm{NO}_{3}\right)_{2} \cdot 6 \mathrm{H}_{2} \mathrm{O} \text {, } \\
\text { Fe }\left(\mathrm{NO}_{3}\right)_{3} \cdot 9 \mathrm{H}_{2} \mathrm{O} \text {, and } \mathrm{AgNO}_{3} \text { in the presence of the } \\
\text { GO powder. }\end{array}$ & [53] \\
\hline 6 & $\mathrm{GO}-\mathrm{NiFe}_{2} \mathrm{O}_{4}$ & $\begin{array}{c}\mathrm{GO} \text { in } \mathrm{NiFe}_{2} \mathrm{O}_{4} \text { was dispersed in deionized water. } \\
\text { Then, } \mathrm{NiSO}_{4} \mathrm{H}_{2} \mathrm{O} \text { and } \mathrm{FeCl}_{3} \cdot 6 \mathrm{H}_{2} \mathrm{O}(0.02 \mathrm{~mol}) \text { were } \\
\text { dissolved in } 15 \mathrm{~mL} \text { water. Transferred into autoclave } \\
\text { and kept under high pressure. }\end{array}$ & [56] \\
\hline 7 & GO-MnFe ${ }_{2} \mathrm{O}_{4}$ & $\begin{array}{l}\mathrm{GO} \text { and } 60 \mathrm{~mL} \text { of ethanol with sonication for } 1 \mathrm{~h} \text { and } \\
\mathrm{Mn}\left(\mathrm{NO}_{3}\right)_{2} \text { solution and Fe }\left(\mathrm{NO}_{3}\right)_{3} \cdot 9 \mathrm{H}_{2} \mathrm{O} \text { were } \\
\text { dissolved. The resulting mixture was transferred into } \\
\text { a } 100 \mathrm{~mL} \text { Teflon-lined stainless-steel autoclave and } \\
\text { heated to } 180{ }^{\circ} \mathrm{C} \text { for } 20 \mathrm{~h} \text { under autogenous pressure. }\end{array}$ & [58] \\
\hline 8 & $\mathrm{rGO}-\mathrm{Bi}_{2} \mathrm{WO}_{6}$ & $\begin{array}{l}\text { GO by using Hammer method GO was reduced by } \\
\left.\text { ethylene glycol. Bi( } \mathrm{NO}_{3}\right)_{3} 5 \mathrm{H}_{2} \mathrm{O} \text { was dispersed into } \\
5 \mathrm{~mL} \text { of } 4 \mathrm{M} \text { nitric acid solution. } \mathrm{Na}_{2} \mathrm{WO}_{4} 2 \mathrm{H}_{2} \mathrm{O} \text { was } \\
\text { dissolved in } 5 \mathrm{~mL} \text { of de-ionized water and then } \\
\mathrm{Na}_{2} \mathrm{WO}_{4} \text { was added dropwise to the solution. }\end{array}$ & [59] \\
\hline \multicolumn{4}{|c|}{ B. Sol-gel method for the synthesis of GO/rGO-NCs photocatalysts } \\
\hline 9 & rGO-TiO 2 & $\begin{array}{l}\text { An aqueous solution of } \mathrm{Ti}(\mathrm{OH})_{4} \text { was added into an } \\
\text { aqueous suspension of GO. }\end{array}$ & [30] \\
\hline 10 & rGO-ZnO & $\begin{array}{c}\text { An aqueous solution of } \mathrm{Zn}(\mathrm{AcO})_{2} \cdot 3 \mathrm{H}_{2} \mathrm{O} \text { was added } \\
\text { into an aqueous suspension of } \mathrm{GO} \text {. }\end{array}$ & [39] \\
\hline
\end{tabular}


Table 1. Cont.

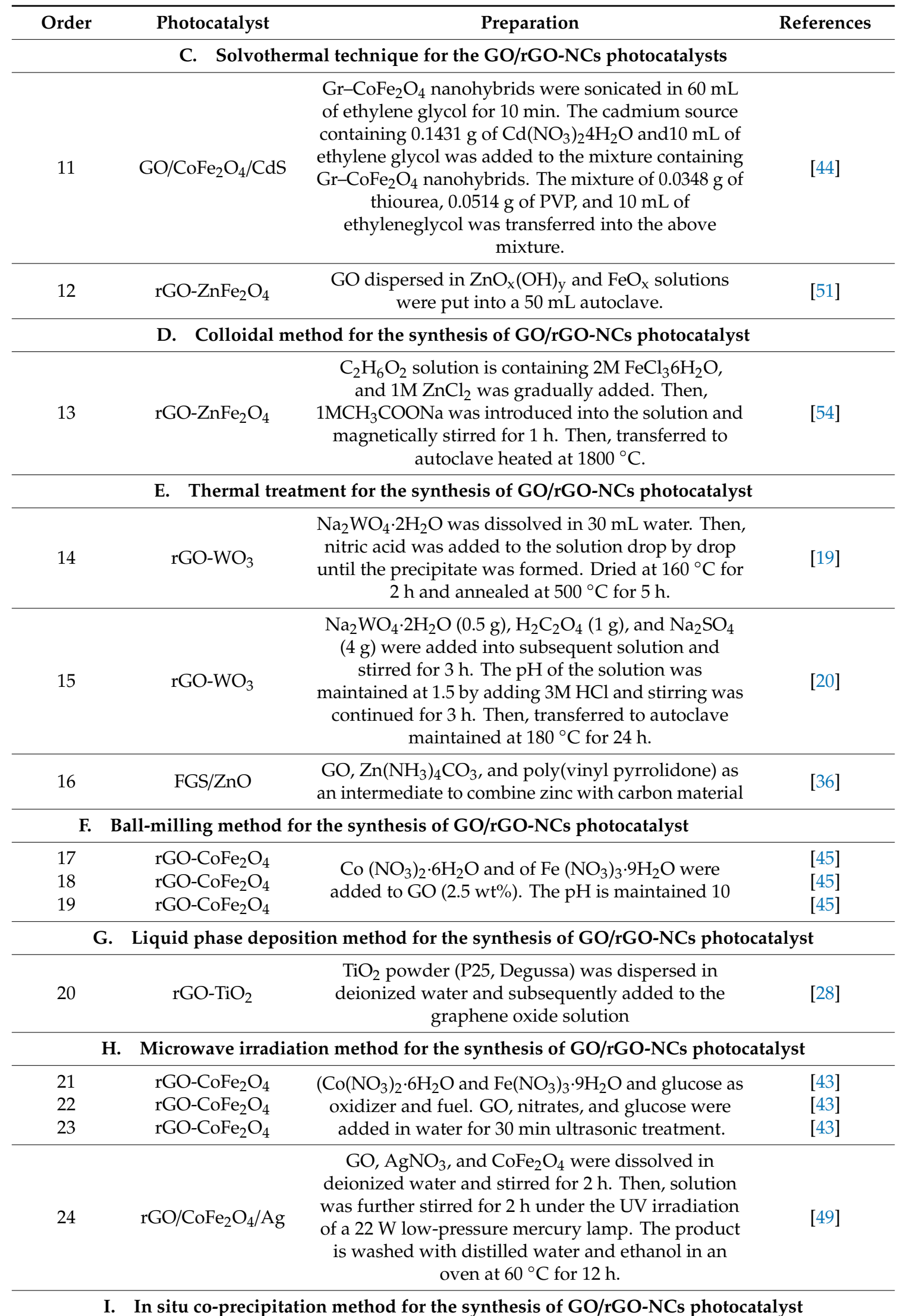

I. In situ co-precipitation method for the synthesis of GO/rGO-NCs photocatalyst 
Table 1. Cont.

\begin{tabular}{|c|c|c|c|}
\hline Order & Photocatalyst & Preparation & References \\
\hline 25 & $\mathrm{rGO}-\mathrm{ZnO}$ & $\begin{array}{l}\text { GO dispersed in aqueous solution containing } \\
\qquad \mathrm{Zn}\left(\mathrm{CH}_{3} \mathrm{COO}\right)_{2}, \mathrm{DMSO} \text {, and } \mathrm{H}_{2} \mathrm{O}\end{array}$ & [40] \\
\hline \multicolumn{4}{|c|}{ J. Annealing $\mathrm{NH}_{3}$ atmosphere method for the synthesis of $\mathrm{GO} / \mathrm{rGO}-\mathrm{NCs}$ photocatalyst } \\
\hline 26 & $\mathrm{rGO} / \mathrm{N}-\mathrm{TiO}_{2}$ & $\begin{array}{c}\mathrm{GO} \text { and } 300 \mathrm{mg} \text { of } \mathrm{P} 90 \mathrm{TiO}_{2} \text { was added and stirred } \\
\text { for } 3 \mathrm{~h} \text {. } \mathrm{GO} \text { and } \mathrm{P} 90 \mathrm{TiO}_{2} \text { and a few drops of } \\
\text { tetrabutyltitanate were added. }\end{array}$ & [31] \\
\hline
\end{tabular}


Table 2. Photocatalytic performances of GO/rGO-NCs photocatalysts for the degradation of pollutant.

\begin{tabular}{|c|c|c|c|c|c|c|c|c|c|c|c|c|}
\hline Order & Pollutants & Photocatalyst & Light Source & Reactor & $\begin{array}{c}\text { Mass of } \\
\text { Catalyst (mg) }\end{array}$ & $\begin{array}{c}\text { Concentration } \\
\text { (ppm) }\end{array}$ & $\begin{array}{l}\text { Irradiation } \\
\text { Time (min) }\end{array}$ & $\begin{array}{c}\text { Conversion } \\
(\%)\end{array}$ & Mol. Wt. & $\begin{array}{l}\text { Photon Flux } \\
\left(\mathrm{mW} \mathrm{cm} \mathrm{cm}^{-2}\right)\end{array}$ & $\begin{array}{l}\text { Quantum } \\
\text { Yield (\%) }\end{array}$ & Reference \\
\hline \multicolumn{13}{|c|}{ A. Photocatalytic performances of GO-rGO semiconductor composites for dye degradation } \\
\hline \multicolumn{13}{|c|}{ A-1. MB } \\
\hline 1 & $\mathrm{MB}$ & rGO-WO $\mathrm{WO}_{3}$ & $\begin{array}{l}\text { light source was a } \\
150 \mathrm{~W} \text { xenon } \\
\text { lamp. }\end{array}$ & $\begin{array}{l}20^{\circ} \mathrm{C} \text { self-made } \\
\text { Lab Solar gas } \\
\text { photocatalysis } \\
\text { system with } \\
\text { external light } \\
\text { irradiation }\end{array}$ & 50 & 7 & 120 & 100 & 2278.4 & NA & NA & [6] \\
\hline 2 & MB & rGO-WO${ }_{3}$ & $\begin{array}{l}\text { One } 300 \mathrm{~W} \\
\text { PLS-SXE } 300 \\
\text { xenon lamp }\end{array}$ & $\begin{array}{l}\text { equipped with } \\
\text { a } \lambda<400 \mathrm{~nm} \\
\text { cut-off filter }\end{array}$ & 20 & 10 & 70 & 95 & 2247.4 & NA & NA & [20] \\
\hline 3 & MB & $\mathrm{rGO} / \mathrm{N}-\mathrm{TiO}_{2}$ & $\begin{array}{c}\text { Two } 20 \mathrm{~W} \\
\text { black-lights with } \\
352 \mathrm{~nm} \text { (UV) and } \\
545 \mathrm{~nm} \text { (Visible) }\end{array}$ & NA & 10 & 8.8 & 60 & $\begin{array}{l}80 \text { (UV) and } \\
95 \text { (Visible) }\end{array}$ & 2123.6 & NA & NA & [28] \\
\hline 4 & MB & $\mathrm{rGO} / \mathrm{N}-\mathrm{TiO}_{2}$ & $\begin{array}{l}\text { one } 500 \mathrm{~W} \text { Xenon } \\
\text { lamp > } 400 \mathrm{~nm}\end{array}$ & Quartz cell & 50 & 8.8 & 160 & 100 & 2137.6 & NA & NA & [31] \\
\hline 5 & MB & rGO-ZnO & $\begin{array}{c}\text { one } 300 \mathrm{~W} \text { Xe } \\
\text { lamp with } 420 \mathrm{~nm}\end{array}$ & NA & 80 & 18 & 70 & 100 & 2125.2 & NA & NA & [39] \\
\hline 6 & MB & rGO-ZnO & $\begin{array}{c}\text { one } 500 \mathrm{~W} \\
\text { mercury lamp }\end{array}$ & NA & 20 & 10 & 90 & 100 & 2125.2 & NA & NA & [40] \\
\hline 7 & MB & $\mathrm{GO} / \mathrm{CoFe}_{2} \mathrm{O}_{4} / \mathrm{CdS}$ & $\begin{array}{c}\text { one } 40 \mathrm{~W} \\
\text { daylight lamp }\end{array}$ & NA & 25 & 20 & 180 & 100 & 2422.8 & NA & NA & [44] \\
\hline 8 & MB & $\mathrm{rGO}-\mathrm{CoFe}_{2} \mathrm{O}_{4}$ & $\begin{array}{l}\text { one } 800 \mathrm{~W} \text { Xe } \\
\text { lamp }\end{array}$ & NA & 10 & 20 & 180 & 100 & 2278.4 & NA & NA & [45] \\
\hline 9 & MB & $\mathrm{rGO}-\mathrm{CoFe}_{2} \mathrm{O}_{4}$ & $\begin{array}{c}\text { A } 100 \mathrm{~W} \text { reading } \\
\text { lamp }\end{array}$ & $\begin{array}{l}\text { installed glass } \\
\text { cut-off filter }\end{array}$ & 25 & 10 & 75 & 90 & 2278.4 & NA & NA & [46] \\
\hline 10 & MB & $\mathrm{rGO}-\mathrm{ZnFe}_{2} \mathrm{O}_{4}$ & $\begin{array}{l}\text { one } 500 \mathrm{~W} \text { xenon } \\
\text { lamp }>420 \mathrm{~nm}\end{array}$ & $\begin{array}{l}\text { Glass reactor } \\
(100 \mathrm{~mL})\end{array}$ & 50 & 10 & 90 & 61 & 2284.7 & NA & NA & [51] \\
\hline 11 & MB & $\mathrm{rGO}-\mathrm{ZnFe}_{2} \mathrm{O}_{4}$ & $\begin{array}{l}\text { one } 530 \mathrm{~W} \text { lamp } \\
\text { with }>400 \mathrm{~nm}\end{array}$ & $\begin{array}{l}\text { Pyrex glass } \\
\text { tube }(100 \mathrm{~mL})\end{array}$ & 25 & 10 & 120 & 100 & 2284.7 & NA & NA & [54] \\
\hline 12 & MB & $\mathrm{NiFe}_{2} \mathrm{O}_{4}-\mathrm{GO}$ & $\begin{array}{c}\text { One } 300 \mathrm{~W} \\
\text { UV-visible lamp }\end{array}$ & $\begin{array}{l}\text { Quartz glass } \\
(100 \mathrm{~mL})\end{array}$ & 100 & 20 & 600 & 90 & 2280.2 & NA & NA & [56] \\
\hline 13 & MB & $\mathrm{MnFe}_{2} \mathrm{O}_{4}-\mathrm{GO}$ & $\begin{array}{l}\text { one } 500 \mathrm{~W} \\
\text { mercury and } \\
\text { xenon lamp }\end{array}$ & $\begin{array}{l}\text { Glass tube } \\
(100 \mathrm{~mL})\end{array}$ & 25 & 20 & 360 & 98 & 2274 & NA & NA & [58] \\
\hline
\end{tabular}


Table 2. Cont

\begin{tabular}{|c|c|c|c|c|c|c|c|c|c|c|c|c|}
\hline Order & Pollutants & Photocatalyst & Light Source & Reactor & $\begin{array}{c}\text { Mass of } \\
\text { Catalyst (mg) }\end{array}$ & $\begin{array}{c}\text { Concentration } \\
(\mathrm{ppm})\end{array}$ & $\begin{array}{l}\text { Irradiation } \\
\text { Time (min) }\end{array}$ & $\begin{array}{c}\text { Conversion } \\
(\%)\end{array}$ & Mol. Wt. & $\begin{array}{l}\text { Photon Flux } \\
\left(\mathrm{mW} \mathrm{cm}^{-2}\right)\end{array}$ & $\begin{array}{l}\text { Quantum } \\
\text { Yield (\%) }\end{array}$ & Reference \\
\hline \multicolumn{13}{|c|}{ A-2. MO } \\
\hline 14 & MO & $\mathrm{rGO}_{-} \mathrm{Co}_{3} \mathrm{O}_{4}$ & $\begin{array}{c}\text { One } 100 \mathrm{~W} \text { Xenon } \\
\text { lamp }\end{array}$ & NA & 10 & 30 & 180 & 80 & 2287 & NA & NA & [21] \\
\hline 15 & MO & rGO- $\mathrm{TiO}_{2}$ & $\begin{array}{c}\text { one } 150 \mathrm{~W} \\
\text { medium-pressure } \\
\text { mercury vapor } \\
\text { lamp with }>350 \\
\mathrm{~nm}\end{array}$ & $\begin{array}{l}\text { quartz } \\
\text { cylindrical } \\
\text { reactor }(7.5 \\
\mathrm{mL})\end{array}$ & 100 & 500 & 30 & 100 & 2123.6 & 6 & NA & [30] \\
\hline 16 & MO & rGO-CoFe2O4 & $\begin{array}{l}\text { one } 800 \mathrm{~W} \text { Xe } \\
\text { lamp }\end{array}$ & NA & 10 & 20 & 180 & 25 & 2278.4 & NA & NA & [45] \\
\hline 17 & MO & rGO-CoFe2O4 & $\begin{array}{c}\text { A } 100 \mathrm{~W} \text { reading } \\
\text { lamp }\end{array}$ & $\begin{array}{c}\text { installed glass } \\
\text { cut-off filter }\end{array}$ & 25 & 10 & 75 & 60 & 2278.4 & NA & NA & [46] \\
\hline \multicolumn{13}{|c|}{ A-3. RhB } \\
\hline 18 & $\mathrm{RhB} 6 \mathrm{G}$ & FGS/ZnO & $\begin{array}{l}\text { Two } 100 \text { and } 250 \\
\text { W high-pressure } \\
\text { mercury lamps } \\
\text { with } 300 \mathrm{~nm}\end{array}$ & $\begin{array}{l}\text { Pyrex glass } \\
\text { tube }(1000 \\
\mathrm{mL})\end{array}$ & 10 & 10 & 100 & 100 & 2125.2 & NA & NA & [36] \\
\hline 19 & $\mathrm{RhB}$ & rGO-CoFe ${ }_{2} \mathrm{O}_{4}$ & $\begin{array}{c}\text { one } 800 \mathrm{~W} \text { Xe } \\
\text { lamp }\end{array}$ & NA & 10 & 20 & 180 & 75 & 2278.4 & NA & NA & [45] \\
\hline 20 & $\mathrm{RhB}$ & rGO-CoFe ${ }_{2} \mathrm{O}_{4}$ & $\begin{array}{c}\text { A } 100 \mathrm{~W} \text { reading } \\
\text { lamp }\end{array}$ & $\begin{array}{c}\text { installed glass } \\
\text { cut-off filter }\end{array}$ & 25 & 10 & 75 & 90 & 2278.4 & NA & NA & [46] \\
\hline 21 & $\mathrm{RhB}$ & rGO-Bi $\mathrm{WO}_{6}$ & $\begin{array}{l}\text { one } 500 \mathrm{~W} \text { Xe } \\
\text { lamp with } 420 \mathrm{~nm}\end{array}$ & $\begin{array}{c}\text { Installed glass } \\
\text { cut-off filter to } \\
\text { visible-light } \\
\text { irradiation } \\
\text { glass tube } \\
(500 \mathrm{~mL})\end{array}$ & 100 & 0.355 & 15 & 98 & 2740.8 & NA & NA & [59] \\
\hline \multicolumn{13}{|c|}{ B. Photocatalytic performances of GO-rGO semiconductor composites for organic pollutants degradation } \\
\hline 22 & sulfamethoxazole & rGO- $\mathrm{WO}_{3}$ & $\begin{array}{l}200 \mathrm{~W} \text { Xe arc } \\
\text { lamp with } \\
\text { specific ranges } \\
420-630 \mathrm{~nm}\end{array}$ & $\begin{array}{l}\text { 1.5 AM solar } \\
\text { simulator }\end{array}$ & 10 & 20 & 180 & 100 & 2247 & NA & NA & [18] \\
\hline 23 & 1-Naphthol & rGO- $\mathrm{WO}_{3}$ & $\begin{array}{l}\text { One Xe lamp } \\
\quad 570 \mathrm{~W}\end{array}$ & $\begin{array}{c}\text { cylindrical } \\
\text { Pyrex reactor } \\
\text { of } 7 \mathrm{~cm} \\
\text { diameter and } \\
15 \mathrm{~cm} \text { height }\end{array}$ & 50 & 150 & 120 & 100 & 2247 & NA & NA & [19] \\
\hline
\end{tabular}


Table 2. Cont

\begin{tabular}{|c|c|c|c|c|c|c|c|c|c|c|c|c|}
\hline Order & Pollutants & Photocatalyst & Light Source & Reactor & $\begin{array}{c}\text { Mass of } \\
\text { Catalyst (mg) }\end{array}$ & $\begin{array}{c}\text { Concentration } \\
\text { (ppm) }\end{array}$ & $\begin{array}{l}\text { Irradiation } \\
\text { Time (min) }\end{array}$ & $\begin{array}{c}\text { Conversion } \\
(\%)\end{array}$ & Mol. Wt. & $\begin{array}{l}\text { Photon Flux } \\
\left(\mathrm{mW} \mathrm{cm} \mathrm{cm}^{-2}\right)\end{array}$ & $\begin{array}{l}\text { Quantum } \\
\text { Yield (\%) }\end{array}$ & Reference \\
\hline 24 & $\begin{array}{l}\text { Chain chlorinated } \\
\text { paraffin's }\end{array}$ & $\mathrm{RGO} / \mathrm{CoFe}_{2} \mathrm{O}_{4} / \mathrm{Ag}$ & $\begin{array}{l}\text { One } 500 \mathrm{~W} \text { xenon } \\
\text { lamp with } 400 \mathrm{~nm}\end{array}$ & $\begin{array}{l}\text { in situ quartz } \\
\text { reaction cell }\end{array}$ & 10 & NA & 720 & 90 & 2386.2 & NA & NA & [49] \\
\hline 25 & $\begin{array}{c}17 \\
\alpha \text {-ethinylestradiol }\end{array}$ & $\mathrm{rGO} / \mathrm{ZnFe}_{2} \mathrm{O}_{4}-\mathrm{Ag}$ & $\begin{array}{c}\text { One } 300 \mathrm{~W} \\
\text { Xe-lamp }\end{array}$ & NA & 100 & 2 & 240 & 100 & 2382 & NA & NA & [53] \\
\hline
\end{tabular}


Furthermore, the self-redox properties of iron and manganese atoms in $\mathrm{MnFe}_{2} \mathrm{O}_{4}$ induced by $\mathrm{S}_{2} \mathrm{O}_{8}{ }^{2-}$ were particularly useful for the generation of $\mathrm{SO}_{4}{ }^{-}$. The quenching tests and electron spin resonance (ESR) display that $h^{+}, \mathrm{O}^{2-}, \mathrm{SO}_{4}^{-}$, and $\mathrm{OH}$ are accountable for decomposition of antibiotics. Overall, irrespective of other parameters, the solvothermal method is best and helps in crystal growing and super saturation is achieved by reducing the temperature in the crystal growth zone.

Further, noble metal $(\mathrm{Ag}, \mathrm{Au}, \mathrm{Cu}$, etc.) exhibits surface plasmon resonance (SPR), which is a characteristic feature. The SPR frequency of the metal particles can be tuned into visible light absorption by shifting the size of the deposited metal particles on the catalyst. Deposited metal is involved in multiple crucial roles, such as serving as a passive electron sink with high capacity to store electrons to suppress photogenerated charge carrier recombination, facilitates rapid dioxygen reduction to generate free radicals and direct excitation of metals, especially under visible light, and vectorial electron transfer to the conduction band (CB) of metal oxide. Thereby, showing improvement in the photocatalysis for the removal of various organic pollutants/dyes.

\section{Perspectives and Challenges}

Graphene nanosheets act as a substrate to support the metal oxides for photocatalytic activity and graphene-based semiconductor photocatalysts are used for environmental remediation. The morphologies of semiconductors, theoretical electronic-structure calculations, and experimental discovery determinations are necessary on GO to persuade the photocatalytic activity, and composition design is an operative method to enhance the photocatalytic properties. Photocatalytic properties depend on the preparative method, and various parameters like initial concentration, oxidant concentration, $\mathrm{pH}$, particle size, number of GO sheets, and source of light should be explored.

The interface regulates the efficacy of the electron-hole separation. Currently, only few methods succeed in unswervingly depicting the interaction of GR and nanoparticles. Atomic force microscopy (AFM), Surface-enhanced Raman scattering (SERS), and scanning transmission electron microscope (STEM) may be the best techniques for determining the interaction of graphene and nanoparticles. Finally, studies on the preparation of a ternary composite as a photocatalyst for both UV and visible-light-driven pollutant photodegradation have been studied and reported. Especially, for the design of ternary composite, magnetic materials such as $\mathrm{Fe}, \mathrm{Co}, \mathrm{Mn}$, etc., as a dopant, and possessing unique advantages, show a remarkable photocatalytic activity and photostability.

Further tasks exist in the application of graphene-based composite for the industrial scale. Some innovative applications of the metal oxide-graphene entail specific understanding between the metal oxides and surface of the graphene, which will have a direct impact on the properties of the composite. Designing a structure for the overall photocatalysis process may require further exploiting of GO by chemically modifying methods. A synthetic approach method of GO-based composite structure by using novel materials has not been achieved to date for photocatalysis, but the solutions to the key challenges appear within reach.

In view of this, graphene-based composites possess diverse potential applications, individually having dissimilar desires concerning material properties, and it can be projected that the research on graphene-composite materials will have an optimistic future.

Author Contributions: Conceptualization: S.M. (Soumen Mandal) and S.M. (Srinivas Mallapur); writing-original draft preparation: S.M. (Soumen Mandal), S.M. (Srinivas Mallapur), M.R., J.K.S., D.-E.L. and T.P.; writing一review and editing: S.M. (Soumen Mandal), S.M. (Srinivas Mallapur), M.R., J.K.S., D.-E.L. and T.P.; supervision: D.-E.L. and T.P.; funding acquisition: D.-E.L. and T.P. All authors have read and agreed to the published version of the manuscript.

Funding: This work was supported by the National Research Foundation of Korea (NRF) grant funded by the Ministry of Science and ICT (MSIT), Korea (No. NRF-2018R1A5A1025137).

Conflicts of Interest: The authors declare no conflict of interest. 


\section{References}

1. Deng, X.; Lü, L.; Li, H.; Luo, F. The adsorption properties of $\mathrm{Pb}$ (II) and $\mathrm{Cd}(\mathrm{II})$ on functionalized graphene prepared by electrolysis method. J. Hazard. Mater. 2010, 183, 923-930. [CrossRef] [PubMed]

2. Yang, S.-T.; Chang, Y.; Wang, H.; Liu, G.; Chen, S.; Wang, Y.; Liu, Y.; Cao, A. Folding/aggregation of graphene oxide and its application in $\mathrm{Cu}^{2+}$ removal. J. Colloid Interface Sci. 2010, 351, 122-127. [CrossRef] [PubMed]

3. Zhang, N.; Qiu, H.; Si, Y.; Wang, W.; Gao, J. Fabrication of highly porous biodegradable monoliths strengthened by graphene oxide and their adsorption of metal ions. Carbon 2011, 49, 827-837. [CrossRef]

4. Yeh, T.-F.; Syu, J.-M.; Cheng, C.; Chang, T.-H.; Teng, H. Graphite Oxide as a Photocatalyst for Hydrogen Production from Water. Adv. Funct. Mater. 2010, 20, 2255-2262. [CrossRef]

5. Zhao, G.; Wen, T.; Chen, C.; Wang, X. Synthesis of graphene-based nanomaterials and their application in energy-related and environmental-related areas. RSC Adv. 2012, 2, 9286-9303. [CrossRef]

6. Li, F.; Tian, X.; Yuhong, Z.; Jun, Y.; Aiwu, W.; Zhong, W. Preparation of $\mathrm{WO}_{3}$-reduced graphene oxide nanocomposites with Enhanced Photocatalytic Property. Ceram. Int. 2015, 41, 5903-5908.

7. Lorestani, F.; Shahnavaz, Z.; Mn, P.; Alias, Y.; Manan, N.S.A. One-step hydrothermal green synthesis of silver nanoparticle-carbon nanotube reduced-graphene oxide composite and its application as hydrogen peroxide sensor. Sens. Actuators B-Chem. 2015, 208, 389-398. [CrossRef]

8. Yu, B.; Xu, J.; Liu, J.-H.; Yang, S.-T.; Luo, J.; Zhou, Q.; Wan, J.; Liao, R.; Wang, H.; Liu, Y. Adsorption behavior of copper ions on graphene oxide-chitosan aerogel. J. Environ. Chem. Eng. 2013, 1, 1044-1050. [CrossRef]

9. Fu, Y.; Wang, J.; Liu, Q.; Zeng, H. Water-dispersible magnetic nanoparticle-graphene oxide composites for selenium removal. Carbon 2014, 77, 710-721. [CrossRef]

10. Li, B.; Liu, T.; Wang, Y.; Wang, Z. ZnO/graphene-oxide nanocomposite with remarkably enhanced visible-light-driven photocatalytic performance. J. Colloid Interface Sci. 2012, 377, 114-121. [CrossRef]

11. Wu, S.; Wang, P.; Cai, Y.; Liang, D.; Ye, Y.; Tian, Z.; Liu, J.; Liang, C. Reduced graphene oxide anchored magnetic $\mathrm{ZnFe}_{2} \mathrm{O}_{4}$ nanoparticles with enhanced visible-light photocatalytic activity. RSC Adv. 2015, 5, 9069-9074. [CrossRef]

12. Tan, L.-L.; Chai, S.-P.; Mohamed, A.R. Synthesis and Applications of Graphene-Based $\mathrm{TiO}_{2}$ Photocatalysts. Chem. Sus. Chem. 2012, 5, 1868-1882. [CrossRef] [PubMed]

13. Li, Y.; Du, Q.; Liu, T.; Peng, X.; Wang, J.; Sun, J.; Wang, Y.; Wu, S.; Wang, Z.; Xia, Y.; et al. Comparative study of methylene blue dye adsorption onto activated carbon, graphene oxide, and carbon nanotubes. Chem. Eng. Res. Des. 2013, 91, 361-368. [CrossRef]

14. Zhang, H.; Lv, X.; Li, Y.; Wang, Y.; Li, J. P25-Graphene Composite as a High Performance Photocatalyst. ACS Nano 2010, 4, 380-386. [CrossRef] [PubMed]

15. An, X.; Yu, J.C. Graphene-based photocatalytic composites. RSC Adv. 2011, 1, 1426-1434. [CrossRef]

16. Du, J.; Lai, X.; Yang, N.; Zhai, J.; Kisailus, D.; Su, F.; Wang, D.; Jiang, L. Hierarchically Ordered Macro-Mesoporous $\mathrm{TiO}_{2}-$ Graphene Composite Films: Improved Mass Transfer, Reduced Charge Recombination, and Their Enhanced Photocatalytic Activities. ACS Nano 2011, 5, 590-596. [CrossRef] [PubMed]

17. Wang, D.; Choi, D.; Li, J.; Yang, Z.; Nie, Z.; Kou, R.; Hu, D.; Wang, C.; Saraf, L.V.; Zhang, J.; et al. Self-Assembled $\mathrm{TiO}_{2}-$ Graphene Hybrid Nanostructures for Enhanced Li-Ion Insertion. ACS Nano 2009, 3, 907-914. [CrossRef]

18. Wenyu, Z.; Faqian, S.; Ronn, G.; Yan, Z. Facile fabrication of RGO-WO $\mathrm{W}_{3}$ composites for effective visible lightphotocatalytic degradation of sulfamethoxazole. Appl. Catal. B 2017, 207, 93-102.

19. Hajishafiee, H.; Sangpour, P.; Tabrizi, N.S. Facile Synthesis and Photocatalytic Performance of $\mathrm{WO}_{3} / \mathrm{rGO}$ Nanocomposite for Degradation of 1-Naphthol. Nano 2015, 10, 1550072. [CrossRef]

20. $\mathrm{Hu}, \mathrm{X}$; $\mathrm{Xu}, \mathrm{P}$; Gong, H.; Yin, G. Synthesis and characterization of $\mathrm{WO}_{3} /$ Graphene nanocomposites for enhanced photocatalytic activities by one-step in-situ hydrothermal reaction. Materials 2018, 11, 147.

21. Wang, W.; Levi, G.; Tade, M.O.; Li, Q. April. Evaluation of Photocatalytic Activity of $\mathrm{Co}_{3} \mathrm{O}_{4} / \mathrm{Graphene}$ Composite. In 2015 International Conference on Materials, Environmental and Biological Engineering; Atlantis Press: Paris, France, 2015; pp. 561-564. 
22. Pervaiz, E.; Liu, H.; Yang, M. Facile synthesis and enhanced photocatalytic activity of single-crystalline nanohybrids for the removal of organic pollutants. Nanotechnology 2017, 28, 105701. [CrossRef] [PubMed]

23. Yao, Y.; Yang, Z.; Sun, H.; Wang, S. Hydrothermal synthesis of $\mathrm{Co}_{3} \mathrm{O}_{4}$-graphene for heterogeneous activation of peroxymonosulfate for decomposition of phenol. Ind. Eng. Chem. Res. 2012, 51, 14958-14965. [CrossRef]

24. Štengl, V.; Bakardjieva, S.; Grygar, T.M.; Bludská, J.; Kormunda, M. TiO ${ }_{2}$-graphene oxide nanocomposite as advanced photocatalytic materials. Chem. Cent. J. 2013, 7, 41. [CrossRef] [PubMed]

25. Zhang, Y.; Tang, Z.R.; Fu, X.; Xu, Y.J. TiO 2 - graphene nanocomposites for gas-phase photocatalytic degradation of volatile aromatic pollutant: Is $\mathrm{TiO}_{2}$-graphene truly different from other $\mathrm{TiO}_{2}$-carbon composite materials? ACS Nano 2010, 4, 7303-7314. [CrossRef] [PubMed]

26. Zhou, K.; Zhu, Y.; Yang, X.; Jiang, X.; Li, C. Preparation of graphene- $\mathrm{TiO}_{2}$ composites with enhanced photocatalytic activity. New J. Chem. 2011, 35, 353-359. [CrossRef]

27. Anandan, S.; Narasinga Rao, T.; Sathish, M.; Rangappa, D.; Honma, I.; Miyauchi, M. Superhydrophilic graphene-loaded $\mathrm{TiO}_{2}$ thin film for self-cleaning applications. ACS Appl. Mater. Interfaces 2013, 5, 207-212. [CrossRef]

28. Nguyen-Phan, T.D.; Pham, V.H.; Shin, E.W.; Pham, H.D.; Kim, S.; Chung, J.S.; Kim, E.J.; Hur, S.H. The role of graphene oxide content on the adsorption-enhanced photocatalysis of titanium dioxide/graphene oxide composites. Chem. Eng. J. 2011, 170, 226-232. [CrossRef]

29. Min, Y.; Zhang, K.; Zhao, W.; Zheng, F.; Chen, Y.; Zhang, Y. Enhanced chemical interaction between $\mathrm{TiO}_{2}$ and graphene oxide for photocatalytic decolorization of methylene blue. Chem. Eng. J. 2012, 193-194, $203-210$. [CrossRef]

30. Pastrana-Martínez, L.M.; Morales-Torres, S.; Likodimos, V.; Figueiredo, J.L.; Faria, J.L.; Falaras, P.; Silva, A.M. Advanced nanostructured photocatalysts based on reduced graphene oxide- $\mathrm{TiO}_{2}$ composites for degradation of diphenhydramine pharmaceutical and methyl orange dye. Appl. Catal. B 2012, 123, 241-256. [CrossRef]

31. Yin, X.; Zhang, H.; Xu, P.; Han, J.; Li, J.; He, M. Simultaneous N-doping of reduced graphene oxide and $\mathrm{TiO}_{2}$ in the composite for visible light photodegradation of methylene blue with enhanced performance. RSC Adv. 2013, 3, 18474-18481. [CrossRef]

32. Chacko, D.K.; Madhavan, A.A.; Arun, T.A.; Thomas, S.; Anjusree, G.S.; Deepak, T.G.; Balakrishnan, A.; Subramanian, K.R.V.; Sivakumar, N.; Nair, S.V.; et al. Ultrafine $\mathrm{TiO}_{2}$ nanofibers for photocatalysis. RSC Adv. 2013, 3, 24858-24862. [CrossRef]

33. Linley, S.; Liu, Y.; Ptacek, C.J.; Blowes, D.W.; Gu, F.X. Recyclable Graphene Oxide-Supported Titanium Dioxide Photocatalysts with Tunable Properties. ACS Appl. Mater. Interfaces 2014, 6, 4658-4668. [CrossRef] [PubMed]

34. Maruthamani, D.; Divakar, D.; Kumaravel, M. Enhanced photocatalytic activity of $\mathrm{TiO}_{2}$ by reduced graphene oxide in mineralization of Rhodamine B dye. J. Ind. Eng. Chem. 2015, 30, 33-43. [CrossRef]

35. Kim, C.H.; Kim, B.; Yang, K.S. $\mathrm{TiO}_{2}$ nanoparticles loaded on graphene/carbon composite nanofibers by electrospinning for increased photocatalysis. In Proceedings of the 2nd International Symposium on Physics and Technology of Sensors (ISPTS), Pune, India, 7-10 March 2015.

36. Yang, Y.; Ren, L.; Zhang, C.; Huang, S.; Liu, T. Facile Fabrication of Functionalized Graphene Sheets (FGS)/ZnO Nanocomposites with Photocatalytic Property. ACS Appl. Mater. Interfaces 2011, 3, $2779-2785$. [CrossRef]

37. Azarang, M.; Shuhaimi, A.; Yousefi, R.; Moradi Golsheikh, A.; Sookhakian, M. Synthesis and characterization of $\mathrm{ZnO} \mathrm{NPs} /$ reduced graphene oxide nanocomposite prepared in gelatin medium as highly efficient photo-degradation of MB. Ceram. Int. 2014, 40, 10217-10221. [CrossRef]

38. Zhang, X.Y.; Li, H.P.; Cui, X.L.; Lin, Y. Graphene/ $\mathrm{TiO}_{2}$ nanocomposites: Synthesis, characterization and application in hydrogen evolution from water photocatalytic splitting. J. Mater. Chem. 2010, 20, 2801-2806. [CrossRef]

39. Li, B.; Cao, H. ZnO@graphene composite with enhanced performance for the removal of dye from water. J. Mater. Chem. 2011, 21, 3346-3349. [CrossRef]

40. Luo, Q.-P.; Yu, X.-Y.; Lei, B.-X.; Chen, H.-Y.; Kuang, D.-B.; Su, C.-Y. Reduced Graphene Oxide-Hierarchical ZnO Hollow Sphere Composites with Enhanced Photocurrent and Photocatalytic Activity. J. Phys. Chem. C 2012, 116, 8111-8117. [CrossRef] 
41. Xitao, W.; Rong, L.; Kang, W. Synthesis of ZnO@ZnS- $\mathrm{Bi}_{2} \mathrm{~S}_{3}$ core-shell nanorod grown on reduced graphene oxide sheets and its enhanced photocatalytic performance. J. Mater. Chem. A 2014, 2, 8304-8313. [CrossRef]

42. Yao, Y.; Yang, Z.; Zhang, D.; Peng, W.; Sun, H.; Wang, S. Magnetic $\mathrm{CoFe}_{2} \mathrm{O}_{4}-$ Graphene Hybrids: Facile Synthesis, Characterization, and Catalytic Properties. Ind. Eng. Chem. Res. 2012, 51, 6044-6051. [CrossRef]

43. Zhang, D.; Pu, X.; Gao, Y.; Su, C.; Li, H.; Li, H.; Hang, W. One-step combustion synthesis of $\mathrm{CoFe}_{2} \mathrm{O}_{4}$-graphene hybrid materials for photodegradation of methylene blue. Mater. Lett. 2013, 113, 179-181. [CrossRef]

44. Shi, Y.; Zhou, K.; Wang, B.; Jiang, S.; Qian, X.; Gui, Z.; Yuen, R.K.; Hu, Y. Ternary graphene-CoFe ${ }_{2} \mathrm{O}_{4} / \mathrm{CdS}$ nanohybrids: Preparation and application as recyclable photocatalysts. J. Mater. Chem. A 2014, 2, 535-544. [CrossRef]

45. He, G.; Ding, J.; Zhang, J.; Hao, Q.; Chen, H. One-Step Ball-Milling Preparation of Highly Photocatalytic Active $\mathrm{CoFe}_{2} \mathrm{O}_{4}$-Reduced Graphene Oxide Heterojunctions for Organic Dye Removal. Ind. Eng. Chem. Res. 2015, 54, 2862-2867. [CrossRef]

46. Moitra, D.; Chandel, M.; Ghosh, B.K.; Jani, R.K.; Patra, M.K.; Vadera, S.R.; Ghosh, N.N. A simple 'in situ' co-precipitation method for the preparation of multifunctional $\mathrm{CoFe}_{2} \mathrm{O}_{4}$-reduced graphene oxide nanocomposites: Excellent microwave absorber and highly efficient magnetically separable recyclable photocatalyst for dye degradation. RSC Adv. 2016, 6, 76759-76772. [CrossRef]

47. Suwanchawalit, C.; Somjit, V. Hydrothermal synthesis of magnetic $\mathrm{CoFe}_{2} \mathrm{O}_{4}$-graphene nanocomposite with enhanced photocatalytic performance. Dig. J. Nanomater. Biostruct. 2015, 10, 769-777.

48. Haw, C.; Chiu, W.; Abdul Rahman, S.; Khiew, P.; Radiman, S.; Abdul Shukor, R.; Hamid, M.A.A.; Ghazali, N. The design of new magnetic-photocatalyst nanocomposites $\left(\mathrm{CoFe}_{2} \mathrm{O}_{4}-\mathrm{TiO}_{2}\right)$ as smart nanomaterials for recyclable-photocatalysis applications. New J. Chem. 2016, 40, 1124-1136. [CrossRef]

49. Chen, X.; Zhao, Q.; Li, X.; Wang, D. Enhanced photocatalytic activity of degrading short chain chlorinated paraffins over reduced graphene oxide/ $\mathrm{CoFe}_{2} \mathrm{O}_{4} / \mathrm{Ag}$ nanocomposite. J. Colloid Interface Sci. 2016, 479, 89-97. [CrossRef]

50. Devi, L.G.; Srinivas, M. Hydrothermal synthesis of reduced graphene oxide-CoFe $\mathrm{O}_{4}$ heteroarchitecture for high visible light photocatalytic activity: Exploration of efficiency, stability and mechanistic pathways. J. Environ. Chem. Eng. 2017, 5, 3243-3255. [CrossRef]

51. Fu, Y.; Wang, X. Magnetically Separable $\mathrm{ZnFe}_{2} \mathrm{O}_{4}-$ Graphene Catalyst and its High Photocatalytic Performance under Visible Light Irradiation. Ind. Eng. Chem. Res. 2011, 50, 7210-7218. [CrossRef]

52. Yang, D.; Feng, J.; Jiang, L.; Wu, X.; Sheng, L.; Jiang, Y.; Wei, T.; Fan, Z. Photocatalyst Interface Engineering: Spatially Confined Growth of $\mathrm{ZnFe}_{2} \mathrm{O}_{4}$ within Graphene Networks as Excellent Visible-Light-Driven Photocatalysts. Adv. Funct. Mater. 2015, 25, 7080-7087. [CrossRef]

53. Khadgi, N.; Li, Y.; Upreti, A.R.; Zhang, C.; Zhang, W.; Wang, Y.; Wang, D. Enhanced Photocatalytic Degradation of $17 \alpha$-Ethinylestradiol Exhibited by Multifunctional $\mathrm{ZnFe}_{2} \mathrm{O}_{4}-\mathrm{Ag} / \mathrm{rGO}$ Nanocomposite Under Visible Light. Photochem. Photobiol. 2016, 92, 238-246. [CrossRef] [PubMed]

54. Jenita Rani, G.; Jothi Rajan, M.A.; Gnana kumar, G. Reduced graphene oxide/ $\mathrm{ZnFe}_{2} \mathrm{O}_{4}$ nanocomposite as an efficient catalyst for the photocatalytic degradation of methylene blue dye. Res. Chem. Intermed. 2017, 43, 2669-2690. [CrossRef]

55. Fu, Y.; Chen, H.; Sun, X.; Wang, X. Graphene-supported nickel ferrite: A magnetically separable photocatalyst with high activity under visible light. AIChE J. 2012, 58, 3298-3305. [CrossRef]

56. Liu, S.-Q.; Xiao, B.; Feng, L.-R.; Zhou, S.-S.; Chen, Z.-G.; Liu, C.-B.; Chen, F.; Wu, Z.-Y.; Xu, N.; Oh, W.-C.; et al. Graphene oxide enhances the Fenton-like photocatalytic activity of nickel ferrite for degradation of dyes under visible light irradiation. Carbon 2013, 64, 197-206. [CrossRef]

57. Zeng, J.; Song, T.; Lv, M.; Wang, T.; Qin, J.; Zeng, H. Plasmonic photocatalyst Au/g- $\mathrm{C}_{3} \mathrm{~N}_{4} / \mathrm{NiFe}_{2} \mathrm{O}_{4}$ nanocomposites for enhanced visible-light-driven photocatalytic hydrogen evolution. RSC Adv. 2016, 6, 54964-54975. [CrossRef]

58. Fu, Y.; Xiong, P.; Chen, H.; Sun, X.; Wang, X. High Photocatalytic Activity of Magnetically Separable Manganese Ferrite-Graphene Heteroarchitectures. Ind. Eng. Chem. Res. 2012, 51, 725-731. [CrossRef]

59. Gao, E.; Wang, W.; Shang, M.; Xu, J. Synthesis and enhanced photocatalytic performance of graphene- $\mathrm{Bi}_{2} \mathrm{WO}_{6}$ composite. Phys. Chem. Chem. Phys. 2011, 13, 2887-2893. [CrossRef] 
60. Li, Z.; Shen, Y.; Yang, C.; Lei, Y.; Guan, Y.; Lin, Y.; Liu, D.; Nan, C.-W. Significant enhancement in the visible light photocatalytic properties of $\mathrm{BiFeO}_{3}$-graphene nanohybrids. J. Mater. Chem. A 2013, 1, 823-829. [CrossRef]

61. Lee, S.; Amaranatha Reddy, D.; Kim, T.K. Well-wrapped reduced graphene oxide nanosheets on $\mathrm{Nb}_{3} \mathrm{O}_{7}(\mathrm{OH})$ nanostructures as good electron collectors and transporters for efficient photocatalytic degradation of rhodamine B and phenol. RSC Adv. 2016, 6, 37180-37188. [CrossRef]

Publisher's Note: MDPI stays neutral with regard to jurisdictional claims in published maps and institutional affiliations.

(C) 2020 by the authors. Licensee MDPI, Basel, Switzerland. This article is an open access article distributed under the terms and conditions of the Creative Commons Attribution (CC BY) license (http://creativecommons.org/licenses/by/4.0/). 